\title{
Detection of Retention Trees on Clearcuts, a 50-Year Perspective
}

\author{
Emma Holmström ${ }^{1 *}{ }^{\mathbb{D}}$, Ellen Nordström¹, Delphine Lariviére ${ }^{1,2}$, Ida Wallin ${ }^{3}$ \\ ${ }^{1}$ Southern Swedish Forest Centre, Swedish University of Agricultural Science, Alnarp, Sweden \\ ${ }^{2}$ The Forestry Research Institute of Sweden, Skogforsk, Ekebo, Svalöv, Sweden \\ ${ }^{3}$ Chair of Forest and Environmental Policy, University of Freiburg, Tennenbacherstr, Freiburg, Germany \\ Email: *emma.holmstrom@slu.se
}

How to cite this paper: Holmström, E., Nordström, E., Lariviére, D., \& Wallin, I. (2020). Detection of Retention Trees on Clearcuts, a 50-Year Perspective. Open Journal of Forestry, 10, 110-123. https://doi.org/10.4236/ojf.2020.101008

Received: December 3, 2019

Accepted: January 3, 2020

Published: January 6, 2020

Copyright $\odot 2020$ by author(s) and Scientific Research Publishing Inc. This work is licensed under the Creative Commons Attribution International License (CC BY 4.0).

http://creativecommons.org/licenses/by/4.0/

\begin{abstract}
Changes in clearcut management over time were evaluated using aerial photographs taken between 1960 and 2010. Temporal changes were analysed in two different climatic zones in Sweden: a typical boreal forest zone (the coast of Västerbotten County), and the hemi-boreal zone of southern Sweden (represented by Kronoberg County). The study covers the periods before and after the paradigm shift in Swedish forestry caused by the equalization of the production and nature conservation objectives specified in the first paragraph of the Swedish Forestry Act. Photographs were processed to determine clearcut size and shape and to register solitary retention trees and groups of retention trees. Small but significant changes in clearcut size were detected over time. The number of retention trees increased over time, a result that was also found in other studies using different methodologies. The results demonstrate that measurable structural changes have occurred in Swedish forests over the 25 years since the paradigm shift. Results from this study also show that digital detection of green tree retention could be a future complement to field inventory and monitoring.
\end{abstract}

\section{Keywords}

Forestry, Clearcut, Aerial Photographs, Swedish Forestry Model, Retention Forestry

\section{Introduction}

Striking a balance between multiple objectives within sustainable forest management is one of the greatest challenges for forestry. During the last decades, shifting to a management approach which includes multiple ecosystem services 
has been one important step to sustainable development (D'Amato, Jokela, O’Hara, \& Long, 2018; Messier et al., 2019; Messier et al., 2015; Puettmann \& Ammer, 2007). Highly mechanized and intensive forestry production has increased the efficiency and profitability in forestry but has adversely affected biodiversity (Bremer \& Farley, 2010; da Silva et al., 2019; Enander, 2007; Li, Dang, \& Ambebe, 2009). Swedish forests have traditionally been managed to provide a multitude of ecosystem services, such as mushroom and berry picking, and recreational values (Eckerberg, 1995). However, forest operations such as harvest and regeneration efforts have been optimized for wood extraction and clearcutting was the dominant forest management system in Sweden during the latter part of the last century (Lisberg Jensen, 2011). In this regime, the forest is divided into smaller or larger stands in which all trees are harvested at the same time, creating gaps known as clearcuts that are subsequently filled by a regeneration of even-aged trees.

The sizes of forest-stands and clearcuts correlate strongly with forests' ownership structures. Since the privatization of crown land two centuries ago (Nylund \& Ingemarson, 2007), Sweden's forests have predominantly been owned and managed by Non-Industrial Private Forest (NIPF) owners. In 2017, 319,649 individual NIPF owners held $48 \%$ of Sweden's productive forestland, with an average forest holding of 49 ha productive forestland per owner (SFA, 2018, 2019). The average forest holding for all forest owner types was at this time 100 ha (SFA, 2018). There is considerable variation in ownership structures and sizes of forest holdings between geographical regions. In general, small-scale NIPF owners dominate in southern Sweden, while industrial large-scale owners are more prominent in the North. The average forest holding size for all forest owner types ranges from 50 ha in the south (Götaland) to 221 ha in the north (Norrland) (SFA, 2018).

Following the mechanized intensification of forestry and the introduction of the clearcutting regime in the mid- $20^{\text {th }}$ century, strong environmental concerns were raised by the public, eventually contributing to a major reshaping of forest legislation in the early 1990's (Simonsson, Gustafsson, \& Ostlund, 2015). Decades of heated public debate created political momentum for change, resulting in the passage of a new Forestry Act in 1993 that remains in effect today (Nylund, 2009). The new act's main purpose was to equalize the importance of the production and nature conservation objectives of forest management, which are discussed in the act's first paragraph. This new direction was coupled with the removal of several rules and regulations such as pre-commercial thinning in young stands or to harvest and regenerate unproductive stands (Nylund, 2010). The change in policy has been called a paradigm shift; the current paradigm is known as the Swedish Forestry Model. This model addresses sectorial responsibility for production and biodiversity maintenance in the forest, requiring the sector, industries, landowners, and other actors to take common responsibility for compliance with the law (KSLA, 2009). One element of the Swedish Forestry Model is the large-scale introduction of forestry certification. In 2017, over 12 
million ha of forests were certified according to the FSC standard and 15.8 million ha were PEFC certified (FSC, 2018; PEFC, 2017). The 1993 Forestry Act and introduction of certification standards were thus important milestones in Swedish forestry. Since the new forest legislation was passed, a very technical debate has erupted about which strategy and forest management systems can best meet the twin goals of high production and nature conservation (Hoogstra-Klein, Brukas, \& Wallin, 2017). Improved knowledge of forest ecology, the rising demand for environmentally friendly products, and the increasing prioritization of environmental conservation in public opinion (Eriksson, 2012; Messier et al., 2019), continue to stimulate the search for better ways of maintaining biodiversity and high productivity (Eriksson \& Hammer, 2006). This search is further motivated by the increasing public concern about climate change and the need for mitigation, adaptation, and carbon storage.

The commitment to maintaining biodiversity has prompted far-reaching modifications of the clearcutting regime and forest management systems (Fedrowitz et al., 2014; Franklin \& Johnson, 2012; Gustafsson et al., 2012; Lindenmayer et al., 2012). First, retention tree management measures are now required by both the law and certification schemes. The certification schemes in particular have detailed requirements regarding green tree retention. For example, current regulations state that foresters must retain 10 larger green trees per hectare after clear-felling. This represents a substantial investment for the forest owners and forestry industry. Various studies have demonstrated significant increases in the prevalence of features linked to conservation, including lone retention trees, groups of trees, or riparian and buffer zones (Kruys, Fridman, Gotmark, Simonsson, \& Gustafsson, 2013). These measures have resulted in forest management recommendations that include more mixed and structurally complex stands than earlier in cultivated forest (Agestam, Karlsson, \& Nilsson, 2005; Felton et al., 2016). Additionally, the directives for performing clearcutting have changed. Both the law and the certification schemes impose requirements relating to the form and size of clearcuts, stipulating that they should follow natural variations in the forest landscape rather than making straight lines.

Twenty-five years after the paradigm shift, there is a need to sustain and develop these investments. However, very little relevant information has been digitalized or archived. Modern forest machineries are equipped with GPS devices that allow them to mark the locations of specific conservation features and directly digitize the data for archival. However, such machines only came into use in the 1990s. Consequently, there is a lack of information on conservation measures implemented during or after earlier clearcuts. No large-scale database or monitoring system is implemented for monitoring the conservation measures taken although the Swedish National Forest Inventory register some of the indicators, such as retention trees on clearcuts and it has been analyzed in a previous study (Kruys et al., 2013). There is thus a need for tools that can monitor these features throughout the stand rotation by first locating them and then enabling follow-up work over subsequent decades. 
In this work, changes in clearcut management over time were estimated, using aerial photographs taken over a period of 50 years between 1960 and 2013. Temporal changes were studied in two different climatic zones in Sweden; a typical boreal forest zone (the coastal region of Västerbotten County), and a hemi-boreal region in southern Sweden (Kronoberg County). To assess changes in management practices over time, the size, shape, and abundance of clearcuts were determined. In addition, different types of retention trees in the clearcuts were detected and changes in their abundance over time were analysed.

Three hypotheses were evaluated. The first hypothesis was that the average clearcut size did not change over time or between regions. The second was that number of clearcuts with retention trees did not change over time or between regions, and neither did the number of detectable retention trees. In addition, the proportion of broadleaved or coniferous retention trees was investigated in a similar manner. Finally, the shape of the clearcuts was hypothesized to change over time, as an adjustment to a higher degree of conservation management.

\section{Material and Methods}

A study was conducted to determine how aerial photographs, delivered by the national cadastrial service (Lantmäteriet, 2017) could be used to monitor and describe retention tree management in clearcuts. This study also evaluated differences in management practices over time (between 1960 and 2013) and in different regions. Two regions in Sweden were chosen, representing southern and northern parts of the country: the county of Kronoberg (KB) and the coastal parts of Västerbotten (VB) county (Figure 1, Table 1). Three study areas were randomly selected in each region, giving six areas in total. The study areas were circular sample plots delineated in a GIS software package (ArcGIS ${ }^{\oplus}$ software by Esri. ArcGIS ${ }^{\circledast}$ and ArcMap $^{\mathrm{TM}}$ ), each with an area of 10,000 ha.

In the southern study area, Kronoberg County, NIPF owners own $78 \%$ of the productive forestland. The average forest holding for all ownership types in this

Table 1. Regional data for Kronoberg and Västerbotten (Johansson \& Lidestav, 2011; LST, 2016a, 2016b; SFA, 2019).

\begin{tabular}{ccc}
\hline County statistics 2016 & Kronoberg & Västerbotten \\
Areal $\left(\mathrm{km}^{2}\right)$ & 9426 & 55,432 \\
Proportion of Sweden & 2 & 13 \\
Citizens & 191,000 & 263,378 \\
Precipitation $\left(\mathrm{mm} \cdot\right.$ year $\left.^{-1}\right)$ & $500-1000$ & $500-700$ \\
Climatic zone & III and IV & V, VI and VII \\
Potential production $\mathrm{m}^{3} \cdot \mathrm{year}^{-1} \cdot \mathrm{ha}^{-1}$ & 9.1 & 3.3 \\
Forest estate & 11,000 & 18,746 \\
Number of forest owners & 14,000 & 23,940 \\
Average size of forest estates (ha) & 54 & 170 \\
\hline
\end{tabular}




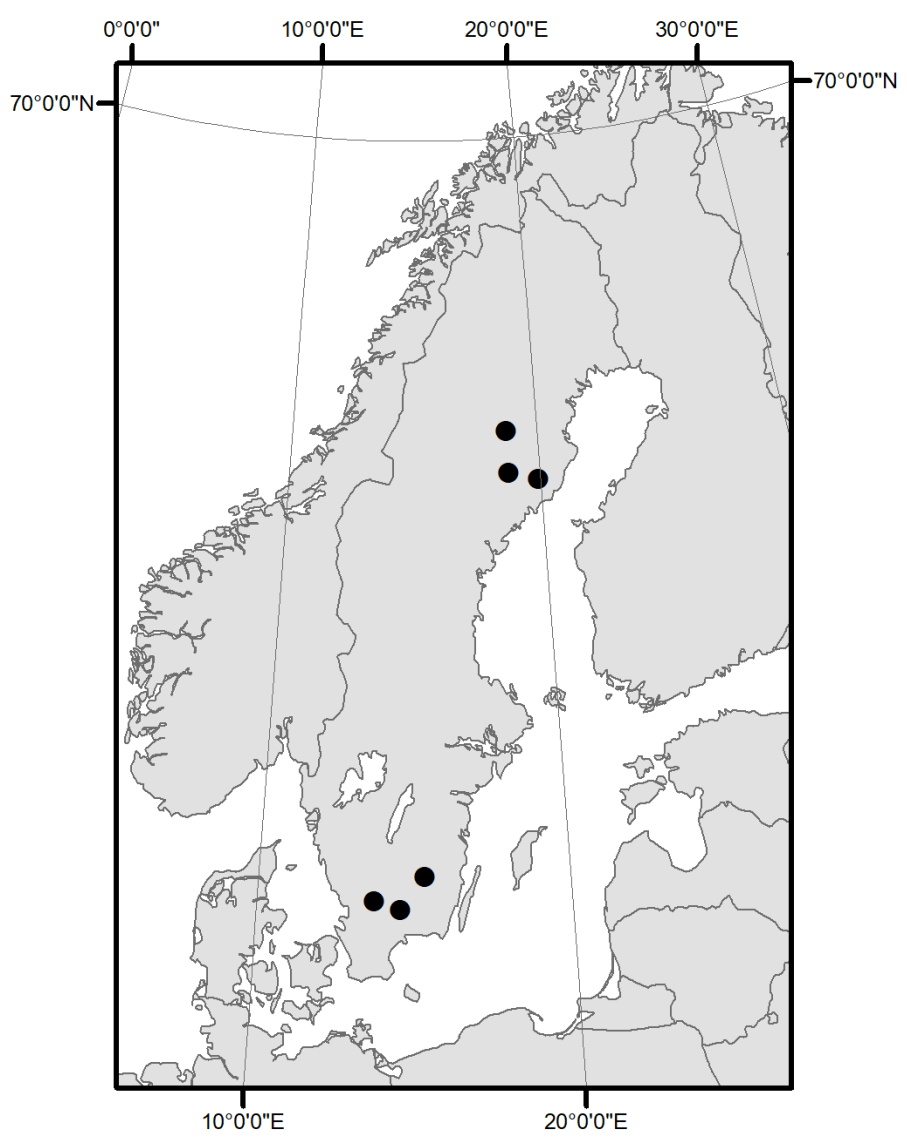

Figure 1. Map over Sweden and the northern and southern study areas marked with black points. Map source Esri., ArcGIS ${ }^{\circledast}$.

region is 54 ha, for NIPF owners 43 ha (SFA, 2019). In contrast, in the northern study area (Västerbotten County), there is a more even mixture of state (31\%) and private industrial (23\%) ownership of productive forestland (ibid.). Here, NIPF owners own $40 \%$ of the forestland and the average forest holding size for all ownership types is 170 ha, for NIPF owners 70 ha (ibid.). The study area is representative of the transitional forest conditions and typical socio-economic settings of Northern Sweden, encompassing both boreal forest and the Fennoscandia Mountains. The Västerbotten study area is also home to an indigenous Sámi population with the right to conduct traditional reindeer herding in the area.

Aerial photography has been performed periodically and systematically in Sweden since 1945. In the early years, the intervals between repeated flyovers and imaging of individual areas were considerably longer than they have been in the last ten years. The standard altitude for aerial photography is $4600 \mathrm{~m}$ above ground level, and the standard pixel resolution is $0.5 \mathrm{~m}$.

The aerial photographs were converted into geometrically corrected orthophotos provided by Lantmäteriet (2017) and used to generate raster layers representing entire regions (Appendix: Table A1). Three-time periods are considered in this study, each represented by a combined layer: one combined layer 
based on photographs taken between 1955 and 1967 (the 1960 layer), one based on photographs from 1993-2005 (the 1990 layer), and one based on photographs from 2010-2013 (the 2010 layer). The 1960 layer represents the era before retention tree management was introduced in Swedish forestry. The 1990 layer represents the transitional period around the implementation of the new forestry act, and the 2010 layer represents contemporary Swedish retention tree management.

Clearcut management was evaluated by analysing clearcut shape, size and frequency. All clearcuts were registered and recorded as manually edited polygons using ArcGIS 10.3. A clearcut was defined as a continuous open harvested area in which bare land was visible between seedlings (Figure 2). Individual continuous clearcut regions were counted as single units, although their owners or other stakeholders might divide them over multiple units or estates. This was done because GIS-analysts cannot identify such internal divisions. The boundary of a clearcut was defined as the edge between the open clearcut and forest, or by the border between the clearcut zone and a different land use category. Breaks in continuity due to small roads, ditches or streams were ignored if there was a coherent open clearcut area on both sides. Clearcut shape was evaluated by computing a shape index that compares the clearcut's actual perimeter and area to those of a square with the same perimeter (for which the shape index is unity). The Shape index is calculated using the expression:

$$
\text { Shape index }=\frac{\frac{\text { Perimeter }}{4}}{\sqrt{\text { Area }}}
$$

where the clearcut's perimeter and area were derived from the created shapefiles. This index was used to approximate the straightness of the clearcut's borders and to monitor changes in the extent to which clearcut shape was adapted to reflect the topography of the terrain. The higher the shape index, the less square the clearcut's shape.

Different tree retention treatments were evaluated separately. Solitary tree retention was defined as the retention of countable single trees on an open clearcut where the density of trees was below 45 trees $\mathrm{ha}^{-1}$. Clearcuts with higher stem
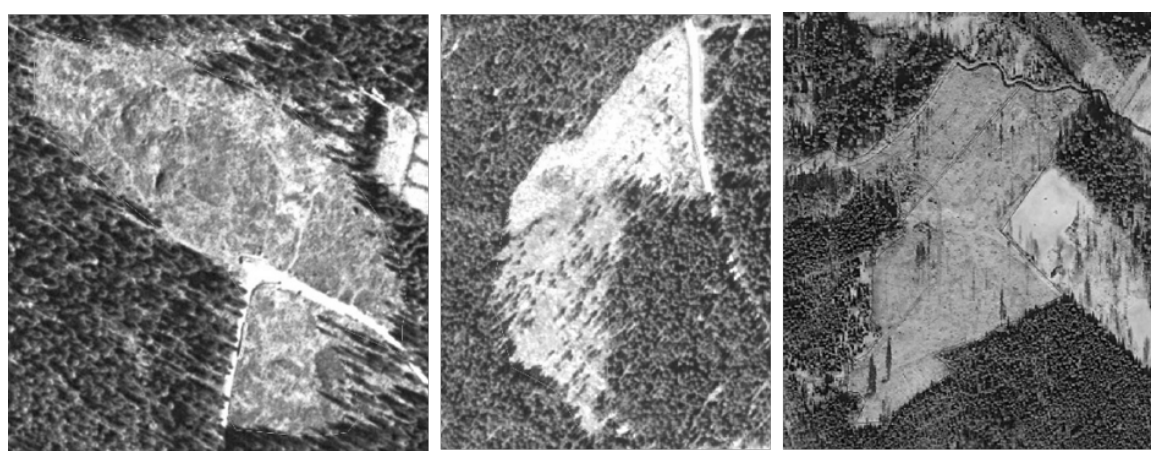

Figure 2. Examples of clearcuts visible in orthophotos from Kronoberg county. From left to right: the 1960, 1990 and 2010 layers. 
density on clearcuts was regarded as ongoing seed tree management, where the trees may be removed as part of the regeneration method. Broadleaved retention trees were mapped but single trees were not counted in species groups. All counts of single retention trees were registered along with the trees' coordinates.

Groups of retained trees were registered if more than three trees were retained in a cluster in which the trees were so close together that it was difficult to distinguish the crowns of individual trees. The cluster areas were defined using polygonal patches and registered separately from the single tree layers.

Riparian zones were evaluated based on the width of the retention zone between the water's edge and the edge of the clearcut. Tree retention in buffer zones on one or both sides of small streams and ditches was registered by recording the zones' widths in metres.

The statistical significance of observed differences between time periods and regions was evaluated using Student's t-test when appropriate, with a confidence threshold of $p<0.05$.

\section{Results}

In Kronoberg, the mean size of clearcuts increased significantly $(p<0.001)$ between 1960 and 1990, from 1.4 ha to 3.7 ha. Between 1990 and 2010, the size of the clearcuts remained unchanged but the number of registered clearcuts increased by $53 \%$ (Figure 3). In this region, clearcuts accounted for $0.7 \%$ of the studied area on average in 1960 and 3\% in 2010. The mean size of the clearcuts in Västerbotten decreased from 14.1 ha in 1960 to 12.6 ha in 1990 and 8.3 ha in 2010. Additionally, the total clearcut area in Västerbotten decreased from $5 \%$ of the study area in 1960 to $3 \%$ in 2010 . The shape index increased significantly over time in Kronoberg $(p<0.001)$ but not in Västerbotten $(p=0.33)$, with an average increase of $9 \%$ and $3 \%$ respectively.

In both counties, the proportion of clearcuts with detectable retention trees increased significantly from 1960 to 2013, from 37\% to 67\% in Västerbotten and from $13 \%$ to $50 \%$ in Kronoberg (Figure 4 ). The proportion of clearcuts with broadleaved retention trees also increased over time: less than $5 \%$ of the clearcuts in the 1960 layer contained detectable broadleaves as retention trees. Conversely, in the 2010 layer, $20 \%$ and $49 \%$ of the clearcuts with retention trees contained retained broadleaves in Kronoberg and Västerbotten, respectively.

The number of solitary retention trees per ha on the clearcuts also increased significantly ( $p<0.001$ ) - by 67\% between 1960 and 2010-in Kronoberg. In Västerbotten, the increase over time was not significant $(p=0.86)$. In addition, the density of solitary retention trees was significantly higher in Kronoberg for all time periods. No correlation was found between the density of solitary retention trees and clearcut size.

Both the proportion of clearcuts with tree retention groups and the number of groups per clearcut increased significantly $(p<0.001)$ in both counties over time. In both counties, the number of groups with retention trees was significantly higher in the 2010 layer than in the 1960 layer $(p<0.001)$. In Kronoberg 


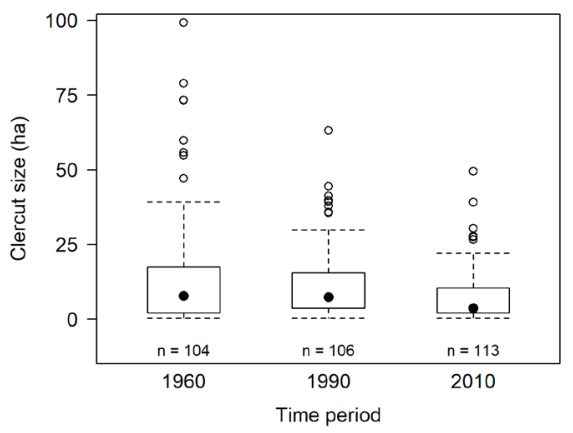

(a)

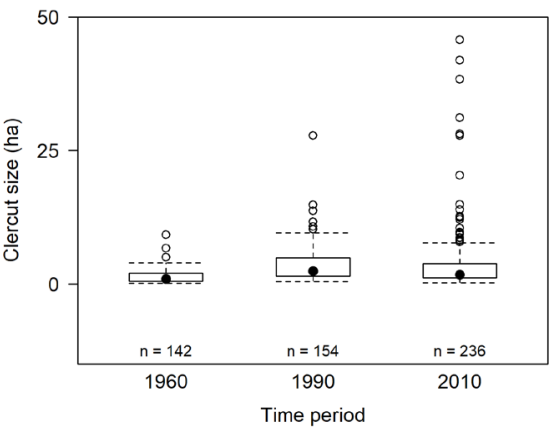

(b)

Figure 3. The mean and the variance of clearcut size in the studied areas and time periods. Numbers of identified clearcuts $(n=\ldots)$ are given inside the panels. The upper panel shows data from Västerbotten and the lower panel shows data Kronoberg county, respectively. Black dots indicate median, the border of the box indicates the first and third quartile, length of whiskers represents approximately 2 standard deviations of the data, and the unfilled dots indicate outliers of the whiskers.

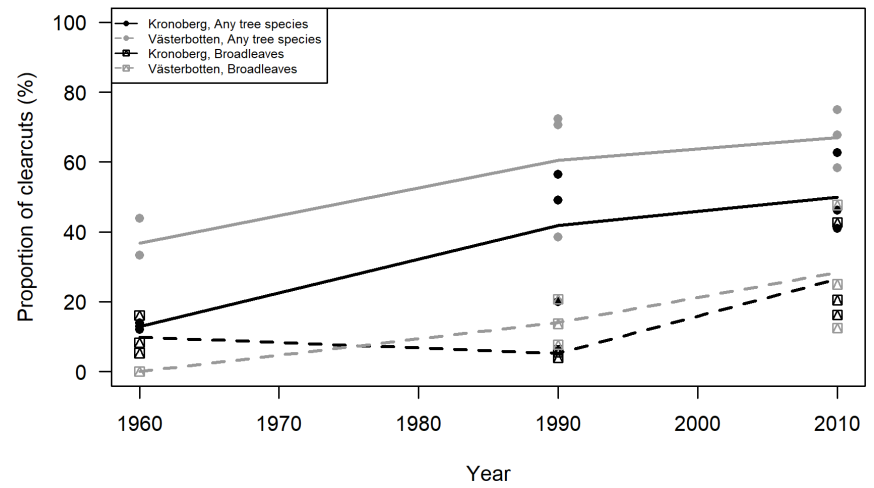

Figure 4. Percentages of clearcuts with solitary retention trees in the study areas, all trees and broadleaves indicated with separate symbols. Points indicating study area values and lines show mean values of the study areas for the counties and time periods respectively.

the density of clusters of retention trees increased from 0.03 groups $^{-1} \mathrm{a}^{-1} 1960$ to 0.06 groups ha ${ }^{-1}$, and in Västerbotten it increased from 0.005 groups $\mathrm{ha}^{-1}$ in 1960 to 0.10 groups $\mathrm{ha}^{-1}$ in 2010.

The proportion of riparian buffer zones around water bodies on the clearcuts increased significantly between 1960 and 2010 in both counties (Kronoberg $p<$ 0.001 , Västerbotten $p=0.04$ ) (Figure 5). In 1960, the proportion of retained riparian zones was less than 10\% whereas in 2010 it was 66\% (Appendix: Table A2). In addition, there was a tendency for the average width of the buffer zone (i.e. the distance between the water edge and the clearcut) to increase over time.

\section{Discussion}

Both studied regions exhibited small but significant changes in clearcut size over time. However, the magnitude of the changes was smaller than the differences between the regions. In Kronoberg county, where the forest estates and management units are smaller, the clearcut size doubled between 1960 and 1990, and 


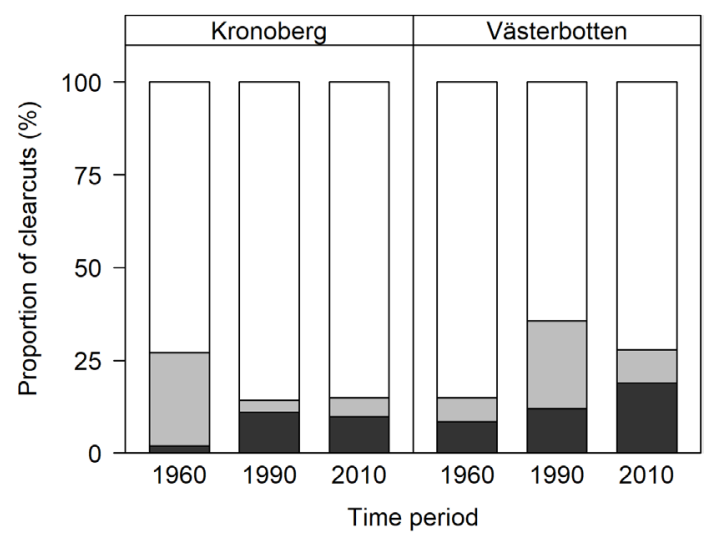

Figure 5. Percentages of clearcuts with no detected streams/ditches (white), without retained buffer zones for detected streams/ditches (grey), and with retained riparian zones (black), in the two counties during the studied time periods.

the total area of clearcuts doubled between 1960 and 2010. This supports the conclusion that clearcut size correlates more strongly with ownership structure than with the introduction of regulatory instruments relating to forest management. However, the increase in the shape index in Kronoberg over time may indicate a higher degree of site adjustment when performing clearcuts. That is to say, forest managers may have compensated for the increased size of clearcuts by creating clearcuts with more flexible boundaries that account for local topography and incorporate small set-aside areas, etc. Additionally, the proportions of solitary and clustered retention trees (both coniferous and broadleaved) have increased, confirming previous reports suggesting that the policy change and paradigm shift that occurred in the early 1990s have increased the structural diversity of clearcuts in comparison to previous management. This increases the potential of more structurally diverse production forests in later stages of forest development.

The effects of implementing retention forestry in Sweden have previously been evaluated by using national forest inventory (NFI) information to compare data on sample plots between years (Kruys et al., 2013). The study presented here demonstrates that the implementation of retention forestry following the passage of the Swedish Forest Act 1993 has increased the retention of dead and living trees after clearcutting. The approach used in this work differs markedly from the NFI approach, in that it focuses on a few study-locations in relatively small areas of Sweden and uses aerial photography instead of field inventory data. Nevertheless, the results obtained are consistent with the earlier report. However, fewer retention trees were identified in this work than in the NFI study, which may indicate that not all retention trees are equally readily identified by analysis of aerial photographs. Another possible explanation is that the NFI does not differentiate between seed tree management and retention trees, which is possible to do with this method. Importantly, this method is also only limited to living retention trees, dead retention trees, in form of high stumps or fallen trees must most likely be studied with other methods. Another drawback 
is that edge zones were difficult to assess based on the aerial photographs and were therefore excluded from this study.

The identification of retained trees adjacent to streams and ditches by analysis of aerial photographs was also tested but the results obtained should be interpreted with care for two reasons. First, the boundaries of the clearcuts in such cases may be quite linear because of the linearity of the bodies of water in the landscape. It is quite likely that linear water bodies such as streams will form natural stand boundaries, and thus will also naturally delimit clearcut sites. Consequently, these landscape elements and their handling by forest managers cannot be properly assessed using the current methodology. Second, the ease of detecting water elements depended on the quality of the aerial photographs. This issue could potentially be resolved in future by using modern depth to water maps or digital elevation models based on high resolution LIDAR scans.

Scholars have highlighted the contradiction implicit in the equalized goal of the Forestry Act and argued that the Swedish Forestry Model represents a wish for "more of everything" (Lindahl et al., 2015). Critics emphasize the trade-off between high production of wood-based products and the preservation of biodiversity. The results presented here show that contemporary forest management practices produce clearcut structures that differ measurably from those formed by the practices common in the 1960s. This is in line with international trends that discuss forest management aiming for increased complexity (Fahey et al., 2018; Gustafsson et al., 2012; Lindenmayer et al., 2012; Messier et al., 2019). These results cannot by themselves be used to determine whether this is sufficient to maintain biodiversity in accordance with the objectives in the Forestry Act, although it demonstrates that today's clearcuts are more structurally diverse than those 50 years ago. This structural diversity has at least the potential to support comparatively more biodiversity and other studies, with focus on how retention forestry affect species taxa and functional groups, show positive effects on abundance and richness both in short and long term perspective (Franklin, Macdonald, \& Nielsen, 2019; Pastur et al., 2019; Savrak, Remm, \& Lohmus, 2019; Sterkenburg, Clemmensen, Lindahl, \& Dahlberg, 2019). However, assessing the extent to which current practices actually supports critical species is outside the scope of this work. In conclusion, this study demonstrates that monitoring some structures of retention forestry could be possible using aerial photographs, especially in combination with other digital information sources and as a complement to field-based national inventories.

\section{Acknowledgements}

This research did not receive any specific grant from funding agencies in the public, commercial, or not-for-profit sectors.

\section{Conflicts of Interest}

The authors declare no conflicts of interest regarding the publication of this paper. 


\section{References}

Agestam, E., Karlsson, M., \& Nilsson, U. (2005). Mixed Forests as a Part of Sustainable Forestry in Southern Sweden. Journal of Sustainable Forestry, 21, 101-117. https://doi.org/10.1300/J091v21n02_07

Bremer, L., \& Farley, K. (2010). Does Plantation Forestry Restore Biodiversity or Create Green Deserts? A Synthesis of the Effects of Land-Use Transitions on Plant Species Richness. Biodiversity and Conservation, 19, 3893-3915. https://doi.org/10.1007/s10531-010-9936-4

D’Amato, A. W., Jokela, E. J., O’Hara, K. L., \& Long, J. N. (2018). Silviculture in the United States: An Amazing Period of Change over the Past 30 Years. Journal of Forestry, 116, 55-67. https://doi.org/10.5849/JOF-2016-035

da Silva, L. P., Heleno, R. H., Costa, J. M., Valente, M., Mata, V. A., Goncalves, S. C., Ramos, J. A. et al. (2019). Natural Woodlands Hold More Diverse, Abundant, and Unique Biota than Novel Anthropogenic Forests: A Multi-Group Assessment. European Journal of Forest Research, 138, 461-472. https://doi.org/10.1007/s10342-019-01183-5

Eckerberg, K. (1995). Multiple-Use Forestry Administration, Legislation and Interest Groups. Vantaa: METLA, Finnish Forest Research Institute, Helsinki Research Centre.

Enander, K.-G. (2007). Skogsbruk på samhällets villkor: Skogsskötsel och skogspolitik under 150 år (9163383276).

Eriksson, L. (2012). Exploring Underpinnings of Forest Conflicts: A Study of Forest Values and Beliefs in the General Public and among Private Forest Owners in Sweden. Society \& Natural Resources, 25, 1102-1117. https://doi.org/10.1080/08941920.2012.657749

Eriksson, S., \& Hammer, M. (2006). The Challenge of Combining Timber Production and Biodiversity Conservation for Long-Term Ecosystem Functioning: A Case Study of Swedish Boreal Forestry. Forest Ecology and Management, 237, 208-217.

https://doi.org/10.1016/j.foreco.2006.09.046

Fahey, R. T., Alveshere, B. C., Burton, J. I., D’Amato, A. W., Dickinson, Y. L., Keeton, W. S., Hardiman, B. S. et al. (2018). Shifting Conceptions of Complexity in Forest Management and Silviculture. Forest Ecology and Management, 421, 59-71. https://doi.org/10.1016/j.foreco.2018.01.011

Fedrowitz, K., Koricheva, J., Baker, S. C., Lindenmayer, D. B., Palik, B., Rosenvald, R., Gustafsson, L. et al. (2014). Can Retention Forestry Help Conserve Biodiversity? A Meta-Analysis. Journal of Applied Ecology, 51, 1669-1679.

https://doi.org/10.1111/1365-2664.12289

Felton, A., Nilsson, U., Sonesson, J., Felton, A., Roberge, J.-M., Ranius, T., Wallertz, K. et al. (2016). Replacing Monocultures with Mixed-Species Stands: Ecosystem Service Implications of Two Production Forest Alternatives in Sweden. Ambio, 45, 124-139. https://doi.org/10.1007/s13280-015-0749-2

Franklin, C. M. A., Macdonald, S. E., \& Nielsen, S. E. (2019). Can Retention Harvests Help Conserve Wildlife? Evidence for Vertebrates in the Boreal Forest. Ecosphere, 10, 1-21. https://doi.org/10.1002/ecs2.2632

Franklin, J. F., \& Johnson, K. N. (2012). A Restoration Framework for Federal Forests in the Pacific Northwest. Journal of Forestry, 110, 429-439.

https://doi.org/10.5849/jof.10-006

FSC (2018). FSC-Certifierad areal och antal certifikatsinnehavare CoC och FM 1998-2017.

https://se.fsc.org/preview.fsc-certifierad-areal-och-antal-certifikatsinnehavare-coc-ochfm-1998-2017.a-1081.pdf 
Gustafsson, L., Baker, S. C., Bauhus, J., Beese, W. J., Brodie, A., Kouki, J., Franklin, J. F. et al. (2012). Retention Forestry to Maintain Multifunctional Forests: A World Perspective. Bioscience, 62, 633-645. https://doi.org/10.1525/bio.2012.62.7.6

Hoogstra-Klein, M. A., Brukas, V., \& Wallin, I. (2017). Multiple-Use Forestry as a Boundary Object: From a Shared Ideal to Multiple Realities. Land Use Policy, 69, 247-258. https://doi.org/10.1016/j.landusepol.2017.08.029

Johansson, J., \& Lidestav, G. (2011). Can Voluntary Standards Regulate Forestry? Assessing the Environmental Impacts of Forest Certification in Sweden. Forest Policy and Economics, 13, 191-198. https://doi.org/10.1016/j.forpol.2010.11.004

Kruys, N., Fridman, J., Gotmark, F., Simonsson, P., \& Gustafsson, L. (2013). Retaining Trees for Conservation at Clearcutting Has Increased Structural Diversity in Young Swedish Production Forests. Forest Ecology and Management, 304, 312-321.

https://doi.org/10.1016/j.foreco.2013.05.018

KSLA (2009). The Swedish Forestry Model. https://www.ksla.se/wp-content/uploads/2010/10/The-Swedish-Forestry-Model.pdf

Lantmäteriet, T. S. M. (2017). Cadastral and Land Registration Authority (Cartographer). https://www.lantmateriet.se

Li, J. L., Dang, Q. L., \& Ambebe, T. F. (2009). Post-Fire Natural Regeneration of Young Stands on Clearcut and Partial-Cut and Uncut Sites of Boreal Mixedwoods. Forest Ecology and Management, 258, 256-262. https://doi.org/10.1016/j.foreco.2009.04.012

Lindahl, K. B., Sténs, A., Sandström, C., Johansson, J., Lidskog, R., Ranius, T., \& Roberge, J.-M. (2015). The Swedish Forestry Model: More of Everything? Forest Policy and Economics, 77, 44-55.

Lindenmayer, D. B., Franklin, J. F., Lohmus, A., Baker, S. C., Bauhus, J., Beese, W., Gustafsson, L. et al. (2012). A Major Shift to the Retention Approach for Forestry Can Help Resolve Some Global Forest Sustainability Issues. Conservation Letters, 5, 421-431. https://doi.org/10.1111/j.1755-263X.2012.00257.x

Lisberg Jensen, E. (2011). Det moderna kalhyggesbruket: Från framgångssaga till förhandlingslösning.

LST (2016a). Länsstyrelsen Kronoberg, fakta om Kronobergs län. https://www.lansstyrelsen.se/kronoberg.html

LST (2016b). Länsstyrelsen Västerbotten, fakta om Västerbottens län. https://www.lansstyrelsen.se/vasterbotten.html

Messier, C., Bauhus, J., Doyon, F., Maure, F., Sousa-Silva, R., Noler, P., Puettmann, K. et al. (2019). The Functional Complex Network Approach to Foster Forest Resilience to Global Changes. Forest Ecosystems, 6, 21. https://doi.org/10.1186/s40663-019-0166-2

Messier, C., Puettmann, K., Chazdon, R., Andersson, K. P., Angers, V. A., Brotons, L., Levin, S. A. et al. (2015). From Management to Stewardship: Viewing Forests as Complex Adaptive Systems in an Uncertain World. Conservation Letters, 8, 368-377. https://doi.org/10.1111/conl.12156

Nylund, J.-E. (2009). Forestry Legislation in Sweden. Uppsala: Dept. of Forest Products, Swedish University of Agricultural Sciences.

Nylund, J.-E. (2010). Swedish Forest Policy since 1990: Reforms and Consequences.

Nylund, J.-E., \& Ingemarson, F. (2007). Forest Tenure in Sweden: A Historical Perspective.

Pastur, G. J. M., Rosas, Y. M., Manriquez, M. T., Herrera, A. H., Miller, J. A., Cellini, J. M., Lencinas, M. V. et al. (2019). Knowledge Arising from Long-Term Research of Variable Retention Harvesting in Tierra del Fuego: Where Do We Go from Here? Ecolog- 
ical Processes, 8, 24. https://doi.org/10.1186/s13717-019-0177-5

PEFC (2017). Statistiksammanställning 2017-12-31.

https://pefc.se/wp-content/uploads/2018/02/PEFC-Statistik-tom-171231.pdf

Puettmann, K. J., \& Ammer, C. (2007). Trends in North American and European Regeneration Research under the Ecosystem Management Paradigm. European Journal of Forest Research, 126, 1-9. https://doi.org/10.1007/s10342-005-0089-z

Savrak, A. L., Remm, L., \& Lohmus, A. (2019). Retention Trees Can Benefit Biodiversity without Significant Long-Term Reduction in Stand Regeneration in Estonian Mixed Forests. European Journal of Forest Research, 138, 513-525.

https://doi.org/10.1007/s10342-019-01187-1

SFA (2018). Statistik om skogsägande 2017.

https://www.skogsstyrelsen.se/globalassets/om-oss/publikationer/2018/rapport-2018-1

2-strukturstatistik-statistik-om-skogsagande-2017.pdf

SFA (2019). Swedish Forest Agency, Statistical Database. https://www.skogsstyrelsen.se/statistik/sveriges-officiella-statistik

Simonsson, P., Gustafsson, L., \& Ostlund, L. (2015). Retention Forestry in Sweden: Driving Forces, Debate and Implementation 1968-2003. Scandinavian Journal of Forest Research, 30, 154-173. https://doi.org/10.1080/02827581.2014.968201

Sterkenburg, E., Clemmensen, K. E., Lindahl, B. D., \& Dahlberg, A. (2019). The Significance of Retention Trees for Survival of Ectomycorrhizal Fungi in Clear-Cut Scots Pine Forests. Journal of Applied Ecology, 56, 1367-1378.

https://doi.org/10.1111/1365-2664.13363 


\section{Appendix}

Table A1. GIS rasters and shapefiles used in the study.

\begin{tabular}{|c|c|c|c|}
\hline Type and name & Format & Publisher/Editor & Usage in study \\
\hline $\begin{array}{l}\text { Orthophoto } \\
\text { 2010-layer }\end{array}$ & Tiff & $\begin{array}{l}\text { Swedish } \\
\text { Cadastrial } \\
\text { Services }\end{array}$ & $\begin{array}{l}\text { Information } \\
\text { source cleacuts }\end{array}$ \\
\hline $\begin{array}{l}\text { Orthophoto } \\
\text { 1990-layer }\end{array}$ & Tiff & $\begin{array}{l}\text { Swedish } \\
\text { Cadastrial } \\
\text { Services }\end{array}$ & $\begin{array}{c}\text { Information } \\
\text { source clearcuts }\end{array}$ \\
\hline $\begin{array}{l}\text { Orthophoto } \\
\text { 1960-layer }\end{array}$ & Tiff & $\begin{array}{l}\text { Swedish } \\
\text { Cadastrial } \\
\text { Services }\end{array}$ & $\begin{array}{c}\text { Information } \\
\text { source clearcuts }\end{array}$ \\
\hline $\begin{array}{l}\text { Topographic } \\
\text { map }\end{array}$ & Tiff & $\begin{array}{l}\text { Swedish } \\
\text { Cadastrial } \\
\text { Services }\end{array}$ & $\begin{array}{l}\text { Extended } \\
\text { knowledge } \\
\text { on land use }\end{array}$ \\
\hline $\begin{array}{l}\text { Clearcut } \\
\text { registrations }\end{array}$ & Shp, polygons & $\begin{array}{l}\text { Swedish } \\
\text { Forest Agency }\end{array}$ & $\begin{array}{c}\text { Extended } \\
\text { knowledge } \\
\text { on clearcut shape }\end{array}$ \\
\hline $\begin{array}{l}\text { Clearcuts 1960, } 1990 \\
\text { and } 2010 \text { layers }\end{array}$ & Shp polygons & $\begin{array}{l}\text { Produced } \\
\text { by authors }\end{array}$ & $\begin{array}{l}\text { Produced layer } \\
\text { in study, clearcuts }\end{array}$ \\
\hline $\begin{array}{c}\text { Retention trees } \\
1960,1990 \text { and } 2010 \text { layer }\end{array}$ & Shp, points & $\begin{array}{l}\text { Produced } \\
\text { by authors }\end{array}$ & $\begin{array}{l}\text { Produced layer } \\
\text { in study, } \\
\text { retention trees }\end{array}$ \\
\hline $\begin{array}{l}\text { Retention tree clusters } \\
1960,1990 \text { and } 2010 \text { layers }\end{array}$ & Shp, polygons & $\begin{array}{l}\text { Produced } \\
\text { by authors }\end{array}$ & $\begin{array}{l}\text { Produced layer } \\
\text { in study, retention } \\
\text { tree clusters }\end{array}$ \\
\hline $\begin{array}{l}\text { Riparian buffer zones, } \\
1960,1990 \text { and } 2010 \text { layers }\end{array}$ & Shp, polygons & $\begin{array}{l}\text { Produced } \\
\text { by authors }\end{array}$ & $\begin{array}{l}\text { Produced layer } \\
\text { in study, } \\
\text { riparian zones }\end{array}$ \\
\hline
\end{tabular}

Table A2. Riparian buffer zones detected in clearcuts. N. clearcut = total number of clearcuts, N. no = number of clearcuts with detected water streams/ditches without riparian zones, $\mathrm{N}$. yes = number of clearcuts with detected water streams/ditches with riparian zones, Mean zone width = measured average buffer zone width $(\mathrm{m})$ perpendicular to the stream/water body.

\begin{tabular}{cccccc}
\hline County & Time period & N. clearcuts & N. no & N. yes & Mean zone width $(\mathrm{m})$ \\
\hline Kronoberg & 1960 & 142 & 26 & 3 & 28 \\
& 1990 & 154 & 5 & 17 & 13 \\
& 2010 & 236 & 12 & 23 & 15 \\
Västerbotten & 1960 & 104 & 7 & 6 & 24 \\
& 1990 & 106 & 10 & 15 & 20 \\
& 2010 & 113 & 7 & 22 & 13
\end{tabular}

